\title{
APPLICATION OF CORPORATE SOCIAL RESPONSIBILITY AND COMPANIES' ENVIRONMENTAL PERFORMANCE
}

\author{
UDC: 330.13:005.35(497.11) \\ 502/504(497.11) \\ Original Scientific Paper \\ Marko ALEKSIĆ ${ }^{1}$, Radmila BJEKIĆ ${ }^{2}$, Marijana RODIĆ ${ }^{3}$ \\ ${ }^{1}$ University of Novi Sad, Faculty of Economics in Subotica, 24000 Subotica, Segedinski put 9-11, \\ Republic of Serbia \\ ${ }^{2}$ University of Novi Sad, Faculty of Economics in Subotica, 24000 Subotica, Segedinski put 9-11, \\ Republic of Serbia \\ E-mail: radmila.bjekic@ef.uns.ac.rs \\ ${ }^{3}$ Gender Equality Institute, 21000 NoviSad, BulevarMihajlaPupina 6, Republic of Serbia
}

Paper received: 04.08.2020.; Paper accepted: 02.10.2020.

\begin{abstract}
Over the years, the irresponsible behavior of individuals and companies through the years created growing social and environmental problems around the world. Globalization, market growth, and industrialization lead to increasingly negative impacts on the natural environment. Socially responsible business is a concept of which the company pays attention to achieving growth and development, and also to cooperate with employees, locals, consumers, business associates, and society as a whole. This paper presents the results of a pilot study conducted on the territory of the Republic of Serbia, Autonomous Province Vojvodina. 53 companies, with over 250 employees, participated in the research. In the paper, the authors presented and evaluated various dimensions of socially responsible business and environmental performance, and based on the obtained results it was determined that there is a statistically positive correlation between these variables.
\end{abstract}

Keywords: Corporate social responsibility; Environment; Serbia.

\section{INTRODUCTION}

Every company is a part of the society in which it operates, so besides achieving their primary economic goals, it is also necessary to take into account both the society and the environment, i.e. to adapt and harmonize their business activities to be socially acceptable (Khojastehpour, \& Shams, 2019). It is very important to define the boundary between the approach to corporate social responsibility as a cost or as an investment (Campbell, 2007). The border between the two depends on how much attention a company pays and what projects it launches, how it defines its goals, as well as the way it promotes its activities. When doing business, it is not enough just to implement the concept of socially responsible business in its business activities and business strategy, but it is also necessary to do it transparently and publicly, so that employees, business associates, and consumers are informed about the undertaken activities. The best results from the application of socially responsible business are achieved by the company if it is implemented strategically and in the long run (Hong, Zhang, \& Ding, 2018).

This paper aims to investigate the relationship between CSR (corporate social responsibility) and the environmental performance of the companies. The subject of the research is the concepts of CSR and environmental performance, as well as the analysis of empirical data related to the environmental performance of companies in the Republic of Serbia. Based on the data obtained from the research conducted during November 2019 through April 2020 in the territory of the Republic of Serbia (AP Vojvodina), and the data obtained by the company's management, it was investigated whether there is a connection between the CSR concept and environmental performance. 53 companies participated in the 
research. The authors tried to point to the connection between the two concepts by reviewing the available literature on CSR and environmental performance, as well as through data analysis,

The paper is composed of three interconnected units. In the first part, the authors discussed the prevailing views on corporate social responsibility and environmental performance. The second part of the paper refers to the analysis of empirical data obtained during the research related to dimensions of CSR and environmental performance of the company. The third part includes the conclusions of the authors' research, emphasizing the positive statistical correlation between the mentioned two concepts.

\section{THEORETICAL BASIS OF RESEARCH}

Even at the time of founding the first companies, there were expectations that their managers and owners were guided by moral principles and that the business of their companies would not adversely affect the environment and society. Socially responsible business, as a concept, has been evaluated for years and today it is very much present in the business of many companies.

The modern economy has often been on the way to lose its connection with life processes and natural resources, which would lead to unforeseeable consequences for the living environment and the lives of future generations (Matešić et al., 2015). Precisely such views were the basis for developing the concept of socially responsible business, as it exists today. Consumers are awakened to the awareness of environmental protection and the importance of corporate social responsibility (Chen, \& Chai, 2010). Such consumer attitudes and numerous actions they have taken together with NGOs encouraged multinational companies to start applying this concept (Idowu, \& Schmidpeter, 2015). The key to the success of many large companies is exactly the implementation of the social responsibility concept by which they gain a significant number of customers and users of their products or services.

The concept of sustainable development and socially responsible business implies establishing a balance between economic, social, and environmental requirements, striving to ensure that the needs of the current generation are met without affecting the reduction of opportunities for future generations to do the same (Mitrović, \& Mitrović, 2019).

Socially responsible business is a concept within which companies, in addition to their primary function of acquiring and distributing profits, direct their activities to achieve a positive impact on the work, social and natural environment (Atanacković, 2011). According to the authors Kotler and Lee (2009), corporate social responsibility is a commitment to improving and achieving benefits for the entire community through business practices they conduct. Social initiatives implemented by companies represent the basis through which they support social goals and fulfill the obligations of socially responsible businesses (Kotler, \& Lee, 2009). CSR comprises economic performance, social accountability, and environmental management and it consists of four kinds of responsibilities: economic, legal, ethical, and philanthropy (Berber et al., 2019a).

One important aspect of the concept of socially responsible business is the environmental aspect, i.e. care for the environment (Aguinis, \& Glavas, 2019). Every company, by performing its activity, in some way contributes to endangering the environment. The goal of applying the concept of socially responsible business is to limit and control the harmful effects on the environment, which are present during all the phases of the business process (Turker, 2009; Valdez-Juárez et al., 2018). Ecological innovations aimed at the successful application of the concept of social responsibility relate to recycling waste materials, construction, industrial waste, development of sewerage infrastructure, electrical installations and water supply in the field of construction, improvement of packaging, transport, keeping and storage methods in the food and beverage industry and the like (Krivokapić et al., 2014).

\section{SOCIALLY RESPONSIBLE BUSINESS IN SERBIA}

When it comes to developing countries, including the Republic of Serbia, the beginning of socially responsible business usually comes from multinational investors who have developed and adopted this concept within their business culture and management in their country. It is this practice of multinational investors that has encouraged some of the local companies to follow them in terms of applying the concept of socially responsible business. In addition to multinational 
investors, the initiators of implementation of this concept in the Republic of Serbia are the media and non-governmental organizations, whose activities have expressed support and initiated implementation. Considering the data on the presence and application of the concept of corporate social responsibility in the Republic of Serbia, it can be concluded that awareness of its benefits is still underdeveloped and that many companies operating in the Republic of Serbia view socially responsible business as unpractical and useless (Marinović, 2007).

Awareness of the concept of socially responsible business and its knowledge shows a tendency to increase from year to year in the Republic of Serbia, but still, a large part of the population does not understand and does not attribute sufficient importance to this concept (Ivanović-Djukić, \& Lepojević, 2015). For the Republic of Serbia, a relatively lower level of application of the concept of socially responsible business is still evident (Krstić et al., 2018; Mijatović et al., 2019). A large number of managers of Serbian companies still hold the opinion that the state is in charge of social problems. While, on the other hand, even the managers who accept the concept of corporate social responsibility in its application do not go beyond one-time financial sponsorships of various sporting, cultural events, donations to hospitals, and the like, considering this type of corporate social responsibility the most beneficial form for the company itself (Petrovic-Lazarevic, \& Prascevic, 2009).

Companies in the Republic of Serbia, within the concept of socially responsible business, pay the most attention to the community. "Socially responsible behavior not only benefits the company, but also the community" (Čelic, 2019). Namely, it is usually the case that companies learn about the needs of the local community and plan and implement activities based on those findings, and the support program they provide at that time is usually one-time or periodic. A small number of companies in the Republic of Serbia have a longterm and strategic approach to socially responsible business.

Furthermore, companies in Serbia place significant emphasis on environmental protection, i.e. the ecological dimension of socially responsible business, which is the most current topic today. Increasingly, environmental standards are being introduced, such as ISO 14001 or some other standard that is specific to the activity in which a particular company is engaged, and relates to environmental protection (Ivanović-Đukić, 2011). Maintenance of city and national parks, their cleaning actions, and similar activities are most often carried out within the concept of socially responsible business, while a small number of Serbian companies provide insight into environmental impact data achieved through their business activities (Mijatović et al., 2019). However, recognizing and assessing the impact of a company and its business on the environment is extremely important. There are several stakeholders for this information. In addition to the company itself and its management, to which business making decisions are important, other interested parties are business associates, suppliers, and customers (Baumgartner, 2014).

In addition to the above, financial support is directed towards education, culture, sports, and the arts.

In comparison with the member states of the European Union, it can be determined that companies in the Republic of Serbia attribute less importance to socially responsible business, and especially to its internal dimension related to ethics in business relations. Namely, the representation of ethics in business relations implies the existence and respect of ethical code (organizational justice) among employees, management, and business owners (Đorđević et al, 2019). Although this concept is known in theory, it has often not been sufficiently applied in the practice of Serbian companies. Lack of moral values in the behavior of managers towards employees occurs in many forms such as non-compliance with employment contracts, overtime unpaid working hours, unregistered workers, illegal termination of employment contracts, and many others (Vuković et al., 2020). Also, the prevalence of corruption is evident. Another important aspect of internal socially responsible business is safety at work, which requires a risk assessment for each job and taking measures to protect employees, namely provision of protective equipment, adequate training, and the like (Damnjanović, 2019). By constantly innovating technology and business processes that are performed in Serbian companies, we try to provide the highest possible level of protection at work.

Poor presence and application of the concept of socially responsible business in the Republic of 
Serbia are attributed to insufficient engagement of state administration. Contribution to the development of socially responsible business would be realized through the following activities (Hajiyev, 2008):

- Establishing a national body whose role would be to encourage and promote socially responsible business, with the definition of proposals for specific measures,

- Increasing the number of media campaigns that would broadcast the defined measures and the national plan on socially responsible business by the state,

- Adoption of laws that would raise the level of mandatory compliance with standards and regulations in the field of corporate social responsibility,

- Implementing control of compliance with these laws,

- Various types of incentives for companies that operate socially responsibly in the form of financial assistance, tax relief, etc.,

- Restructuring operations in public companies and introducing socially responsible operations in them.

The situation with socially responsible business in the Republic of Serbia would also improve if Serbian companies would understand and adopt implementation of this concept as a part of their long-term strategic plan, not just as the way to occasionally promote and attract public attention. Application of the concept of socially responsible business is of the greatest importance for companies that intend to expand their business to the international market, given that consumers and suppliers, as well as business partners from the international market, have more requirements for implementing socially responsible business with the companies they cooperate with.

\section{RELATIONSHIP BETWEEN SOCIALLY RESPONSIBLE BUSINESS AND THE ENVIRONMENT}

According to Radivojević et al., current environmental problems arise mainly from the expanding need for industrialization as a prerequisite for achieving economic growth, but also from the increasing need for urbanization as a necessity of the modern age population around the world (Radivojević et al., 2019). Therefore, one of the most important aspects of socially responsible business is the protection of the environment and its improvement. The importance of this area is based on numerous problems that the environment has been facing for many years, the largest of which is global warming and the depletion of the ozone layer. Also, major environmental disasters that occurred have contributed to raising the global question of how to protect the environment. Namely, in parallel with the development of society and economy, as well as the improvement of the industrial sector, the environment is exposed to significant pollution, energy consumption, endangering the survival of certain biological species and overexploitation of resources. The greatest development of the industry is recorded in the twentieth century, when industrial production experienced a dizzying rise and increase, resulting in increased environmental pollution, which manifested in droughts, forest fires, polluted oceans, radioactive signs in food, lead and mercury in water, drinks and the like (Dramond, \& Bein, 2001).

A significant contribution to environmental preservation can be made by the companies that have the expertise, adequate levels of knowledge, and sufficient financial resources. Precisely because of that, it is necessary to involve the business sector in the field of environmental protection, i.e. it is of great importance that as many companies as possible strive to harmonize and establish a balance between economic growth and profit on the one hand, and preserve and maintain a healthy environment on the other. The aspect of environmental protection within the framework of socially responsible business is very comprehensive and can be implemented through numerous activities (Murdifin et al., 2019). Some of them are the use of renewable energy sources, production of products and services using raw materials and materials that are less harmful to the environment, adequate waste management and compliance with environmental standards, recycling, and the like.

The practice has shown that companies that apply the concept of corporate social responsibility and take into account and apply the concept of environmental protection, adopting environmental standards in their businesses, stand out for competitiveness in the international market, given the increased awareness and consumer awareness of the importance of environmental protection (Grubor et al., 2020). Environmental awareness and consumer sensitivity to environmental issues have been raised to a higher level with an 
increased Internet presence and media influence, and thus more and more companies are being encouraged to develop environmentally friendly products. Companies that show care for the environment are viewed by consumers and other business associates as organizations that don't operate with one goal, which is to achieve and increase profitability, but also take care and invest in future generations (Berber et al., 2019b). A large number of companies that apply the concept of socially responsible business in their business and cooperation with business partners and suppliers set the condition for further cooperation in the field of environmental protection (Vukadinović, \& Ješić, 2019).

One of the ways to protect and improve the environment through the application of socially responsible business involves the application of clean technologies. Their application represents such an approach to the production of each product or service, achieving the use-value by reducing consumption of those resources that cannot be recycled to a minimum level or by minimizing the waste material. An approach to the manufacture of products or services with the application of clean technology means more efficient use of natural resources, reduction of toxic waste and pollution, reduction of production costs, and lower final prices while achieving better product performance.

Performing business activities that are simultaneously harmonized with nature and its conservation, while reducing negative impacts on society, community and economy are characteristics of green business implementation.

\section{RESEARCH METHODOLOGY}

The authors conducted one part of the research through interviews with company managers, and the other part through an online questionnaire in the Republic of Serbia, from November 2019 through April 2020 to collect data on business organizations and their CSR activities and organizational results. The authors used a questionnaire compiled based on various previous studies (Rettab et al., 2009; Saedi et al., 2015; Turker, 2009b). The questionnaire contains three segments. The first segment refers to the basic data of the company, the second part contains questions about CSR and the third part is related to the question about the outcomes of the organization. The main purpose of the research relates to the relationship between the dimension of corporate social responsibility of the companies and environmental performance. Questions related to the company's image are: "Has the company reduced the amount and emissions of pollution?", "Has the company reduced the consumption of hazardous, harmful and toxic substances?", "Has the company reduced the frequency of environmental incidents?", "Has the company reduced energy consumption?", "Has the company improved its environmental situation?". All three segments of questions are defined as closed questions, and the possibility of answers is based on the Likert scale from 1 to 5, (1- I do not agree at all, to 5 - I completely agree).

The research framework is based on an analysis of corporate social responsibility towards different stakeholders. All questions in the questionnaire were evaluated on a Likert scale from 1 to 5 (1 - I strongly disagree; 2 - I disagree; 3 - I neither agree nor disagree; 4 - I agree; 5 - I strongly agree). Questions about the connection between the concept of socially responsible business and organizational performance are taken and adapted from the works of the author Carrol (1979); Weiss, Anderson, \& MacInnis (1999); Maignan and Ferrell (2004); Rettab et al, (2009); Turker (2009); Saeidi et al, (2015). It is a single-respondent questionnaire, i.e. the methodology implies that the answers to the questions are given only by employees in managerial positions familiar with the business of the company as a whole and the ones who have the authority to access such data.

The research involved 53 large companies operating in the Republic of Serbia, AP Vojvodina, where the number of employees is more than 250 . The total number of employees is 64443 employees (34 217 males, 30126 females) (Grubor et al., 2020). Regarding the ownership structure of companies, 49 belong to the private sector (which makes 92\%), 4 belong to the public sector (making it $8 \%$ of the total number). The analyzed companies operate in the following markets: local level $4 \%$, regional level 23\%, national level $30 \%$, international level $36 \%$, and $7 \%$ operate on a global level. Based on the above, it can be concluded that the presence of companies in the international and national market is greater than their presence in global, regional, and local markets (Slavić et al., 2020).

Based on the previously presented in the theoretical part of the paper, the authors proposed the hypothesis: 
H1: There is a positive correlation between the application of corporate social responsibility and companies' environmental performance.

\section{RESEARCH RESULTS AND DISCUSSION}

Correlation analysis was applied to determine the relationship between these phenomena, and the results are shown in Table 1.

Based on data analysis, it can be concluded that the companies have favorable results in terms of environmental performance, i.e. based on five questions (statements) used related to this topic, and their answers were rated with an average value of 4.46. The dimension of CSR related to the environment was rated on average at 4.48 , i.e. the vast majority of managers fully agrees with the above statements. The employee-related CSR dimension is also rated with a higher average of 4.46. The next dimension of social responsibility related to the community was rated on average at 4.22 , and based on the questions asked it can be concluded that most of the surveyed managers agree with the above statements. The attitude of
CSR towards suppliers based on the questions asked was assessed with an average value of 4.37. The mean value of the CSR dimensions related to investors was estimated at 4.05. The customerrelated CSR dimension was rated at an average value of 4.72 , which is also the highest average of all the mentioned dimensions of corporate social responsibility. By analyzing the mean values, it can be concluded that the companies' managers fully agree with the questions (statements) concerning the relationship between corporate social responsibility and environmental performance of the company. The performed correlation analysis shows the existence of a positive statistically significant strong correlation between the dimension of corporate social responsibility related to the environment and environmental performance $(\mathrm{r}=0.531, \mathrm{n}=53, \mathrm{p}$ $<0.01)$. In the performed analysis, the correlation between environmental responsibility and the environmental performance of the company shows that the management team which pays more attention to environmental protection has at the same time better environmental performance.

Table 1: Correlation analysis

\begin{tabular}{|l|c|c|c|c|c|c|c|c|c|}
\hline \multicolumn{1}{|c|}{ FACTORS } & MEAN & SD & 1 & 2 & 3 & 4 & 5 & 6 & 7 \\
\hline $\begin{array}{l}\text { Environmental } \\
\text { performance-1 }\end{array}$ & 4.4566 & 0.81465 & 1 & & & & & & \\
\hline Environment-2 & 4.4858 & 0.85403 & $0.531^{* *}$ & 1 & & & & & \\
\hline Employees-3 & 4.4566 & 0.69324 & 0.502 & $0.382 * *$ & 1 & & & & \\
\hline Community-4 & 4.2170 & 1.04011 & 0.448 & 0.313 & $0.298 *$ & 1 & & & \\
\hline Suppliers-5 & 4.3774 & 0.81303 & 0.270 & 0.537 & 0.358 & 0.148 & 1 & & \\
\hline Investors-6 & 4.0472 & 0.98676 & 0.338 & 0.388 & 0.173 & 0.510 & 0.208 & 1 & \\
\hline Clients-7 & 4.7170 & 0.55478 & 0.258 & 0.499 & 0.158 & 0.485 & 0.362 & 0.244 & 1 \\
\hline
\end{tabular}

**. Correlation is significant at the 0.01 level (2-tailed).

*. Correlation is significant at the 0.05 level (2-tailed).

The following correlation analysis shows the existence of a positive statistically significant strong correlation between the dimension of corporate social responsibility related to employees and environmental performance $(\mathrm{r}=0.382, \mathrm{n}=53$ $\mathrm{p}<0.01$ ), and in this regard, the company's management that provides employees with adequate earnings, supports them in career development, and includes the interests of employees in business decisions, has a better environmental performance in society. The following correlation analysis indicates the existence of a statistically significant weak correlation between the community-related dimension of CSR and environmental performance $(\mathrm{r}=0.298, \mathrm{n}=53, \mathrm{p}<0.05)$. Managers who participate and improve the quality of life in their communities, financially support sports, cultural events as well as educational institutions have a positive attitude towards environmental performance. Correlation analysis shows consistent positive statistically significant weak correlation between the CSR dimension associated with suppliers and environmental performance $(\mathrm{r}=$ 
$0.148, \mathrm{n}=53, \mathrm{p}=<0.05)$. Companies that pay attention to their suppliers for the sake of future business cooperation offer appropriate price discounts positively related to the environmental performance in the company. The next dimension refers to the correlation analysis between CSR related to investors and environmental performance, the analysis found that there is a statistically significant weak correlation among these $(r=0.208, n=53, p=0.05)$. If the company or the management team includes the interests of investors in business decisions, provides investors with an appropriate return on investment, meets the needs and requirements, they at the same time give greater importance to environmental performance. The latest correlation analysis shows the existence of a positive statistically significant weak correlation between the CSR dimension related to customers and the company's environmental performance $(\mathrm{r}=0.244, \mathrm{n}=53, \mathrm{p}=0.05)$. Management with its activities of providing highquality services, necessary information, respecting complaints, adapting to changes to increase the level of customer satisfaction at the same time positively relates to environmental performance in the company.

\section{CONCLUSION}

The basic goal of founding a company can be stated as making products and providing services that meet the needs of consumers and, on that basis, these companies achieve profit and economic growth. However, in addition to achieving economic prosperity, companies need to take into account the society and the natural environment in which they operate, taking care of their impacts. It is companies and their business that are responsible for many activities that have social and environmental significance. Corporate social responsibility and sustainable growth of a company significantly determine its position on the market and affect its image, given that the awareness of preserving the environment and society is growing and becoming an increasingly common topic of global issues.

Due to the growing importance attached to corporate social responsibility, it is believed that in the coming period this concept will begin to be applied by all the companies that want to maintain or improve their position in the market. The mentioned concept is closely related to many functions of the company, and most of all to marketing. The point is that there is a thin line between applying the concept of corporate social responsibility and presenting its results and using corporate social responsibility for marketing purposes.

Some elements of the application of this concept are noticeable, but a small number of companies approach it in the long run and strategically. Implementation of the principles of socially responsible business in Serbian companies requires various incentives from the state. Following the policy of developed countries, where tax relief is provided to organizations that invest in environmental protection, incentives from the state would encourage Serbian companies to raise the level of care for the necessary socially responsible business. Also, in addition to state assistance, the promotion of CSR in schools, colleges, and business networks would lead to greater interest in the opportunities provided by the concept. Taking advantage of the benefits brought by CSR should certainly be one of the drivers for adopting this form of business. In this paper, the emphasis was placed on researching the relationship between CSR and environmental performance. Based on the analysis and the obtained correlation analysis data, it can be concluded that there are statistically significant strong correlations only between the dimensions of corporate social responsibility and environmental performance, while between the other mentioned dimensions there are medium or weak positive correlations. Given the smaller size of an analyzed sample, the authors will expand their research in the future to investigate the proposed relationships in more detail. In this regard, it would be necessary to further stimulate corporate responsibility in the protection and management of the environment. In general, both in the Republic of Serbia and in developing countries, it is necessary to involve all stakeholders in the implementation of such projects. Also, the state would have a significant role in the implementation of this project. Companies in the Republic of Serbia need broad financial and nonfinancial support. In addition to the existence of awareness, it would be necessary to carry out the practical implementation of the principle of social responsibility in legal solutions. It is desirable to follow the policy of developed countries, which, through tax relief, facilitate the consideration of this important aspect of sustainable development. 
M. Aleksić Application of corporate social responsibility and

et al. companies' environmental performance

\section{ACKNOWLEDGEMENTS}

This paper is a part of the research project "Effects of corporate social responsibility in the field of human resources management on the performance and sustainability of organizations" financed by the Provincial Secretariat for Higher Education and Scientific Research of Autonomous Province of Vojvodina, Republic of Serbia. Project Number: 142-451-2482/2019-03.

\section{REFERENCES}

Aguinis, H., \& Glavas, A. (2019). On corporate social responsibility, sensemaking, and the search for meaningfulness through work. Journal of management, 45(3), 1057-1086. doi:10.1177/0149206317691575

Atanacković, U. (2011). Društveno odgovorno poslovanje kao savremeni koncept biznisa. Škola biznisa, 1(2011), 143-148.

Baumgartner, R. J. (2014). Managing corporate sustainability and CSR: A conceptual framework combining values, strategies and instruments contributing to sustainable development. Corporate Social Responsibility and Environmental Management, 21(5), 258-271. doi:10.1002/csr.1336

Berber, N., Slavić, A., \& Aleksić, M. (2019a). The relationship between corporate social responsibility and corporate governance. Ekonomika, 65(3), 1-12. doi:10.5937/ekonomika1903001B

Berber, N., Slavić, A., \& Leković, B. (2019b). A research on the socially responsible human resource management in Serbia. Škola biznisa, (1), 69-85. doi:10.5937/skolbiz1-22913

Campbell, J. L. (2007). Why would corporations behave in socially responsible ways? An institutional theory of corporate social responsibility. Academy of management Review, 32(3), 946-967. doi:10.5465/amr.2007.25275684

Carroll, A. B. (1979). A three-dimensional conceptual model of corporate performance. Academy of Management Review, 4(4), 497-505. doi:10.5465/amr.1979.4498296

Chen, T. B., \& Chai, L. T. (2010). Attitude towards the environment and green products: Consumers' perspective. Management science and engineering, 4(2), 27-39. doi:10.3968/j.mse.1913035X20100402.002

Čelić, I. (2019). The corporate social responsibility in Serbian hospitality industry. Economics of Sustainable Development, 3(2), 21-28. doi:10.5937/ESD1902021C

Damnjanović, M. (2019). Investing in Employees in Serbian Companies-Internal Dimension of CSR. Available at SSRN 3491964.

Dramond, Dž., Bein, B. (2001). Poslovna etika, Klio, Beograd,
Đorđević, B., Ivanović-Đukić, M., Lepojević, V., \& Milanović, S. (2019). The influence of organizational justice on corporate performances. Strategic Management, 24(3), 14-23. doi:10.5937/StraMan1903014D

Grubor, A., Berber, N., Aleksić, M., \& Bjekić, R. (2020). The influence of corporate social responsibility on organizational performances: A research in AP Vojvodina. Anali Ekonomskog fakulteta u Subotici, 56(43). doi:10.5937/AnEkSub2001003G

Hajiyev, E., (2008). Baseline Study on Corporate Social Responsibility Practices in the Western Balkans. UNDP Bratislava Regional Center,

Hong, J., Zhang, Y., \& Ding, M. (2018). Sustainable supply chain management practices, supply chain dynamic capabilities, and enterprise performance. Journal of Cleaner Production, 172, 3508-3519. doi: 10.1016/j.jclepro.2017.06.093

Idowu, S. O., \& Schmidpeter, R. (2015). Corporate social responsibility in Europe: An introduction. In Corporate Social Responsibility in Europe (pp. 114). Springer, Cham.

Ivanovic-Djukic, M., \& Lepojevic, V. (2015). Corporate social responsibility and firm efficiency in Serbia. Engineering Economics, 26(5), 551-559. doi:10.5755/j01.ee.26.5.8756

Ivanović-Đukić, M. (2011). The promotion of corporate social responsibility in Serbia. Sociologija, 53(1), 21-42. doi:10.2298/SOC1101021I

Khojastehpour, M., \& Shams, S. R. (2019). Addressing the complexity of stakeholder management in international ecological setting: A CSR approach. Journal of Business Research.

Kotler, P. \& Lee, N. (2009). Korporativna društvena odgovornost, Hesperia, Beograd

Krivokapić, Z., Vujović, A., \& Jovanović, J. (2014). Environmental innovation in the function social responsibility. FQ2014 festival kvaliteta

Krstić, N., Trbović, A., \& Drasković, B. (2018). Evaluating the strategic approach to CSR in Serbia. Teme, 503-521.

Maignan, I., \& Ferrell, O. C. (2004). Corporate social responsibility and marketing: An integrative framework. Journal of the Academy of Marketing science, 32(1), 3-19. doi:10.1177/0092070303258971

Marinović. N. (2007). Društvena odgovornost preduzeća u Srbiji, trenutno stanje i moguće postojeće inicijative,

Matešić, M., Pavlović, D., \& Bartoluci, D. (2015). Društveno odgovorno poslovanje. VPŠ Libertas,

Mijatovic, I., Maricic, M., \& Horvat, A. (2019). The Factors Affecting the Environmental Practices of Companies: The Case of Serbia. Sustainability, 11(21), 5960. doi: 10.3390/su11215960.

Mitrović, J., \& Mitrović, V. (2019). The development of social entrepreneurship and the perspective of its further affirmation in the overall development of 
Serbia. Anali Ekonomskog fakulteta u Subotici, (42), 81-97. doi:10.5937/AnEkSub1942081M

Murdifin, I., Pelu, M. F. A., Perdana, A. A. H., Putra, K., Arumbarkah, A. M., Muslim, M., \&Rahmah, A. (2019). Environmental disclosure as corporate social responsibility: Evidence from the biggest nickel mining in Indonesia. International Journal of Energy Economics and Policy, 9(1), 115. doi:10.32479/ijeep.7048.

Petrovic-Lazarevic, S., \& Prascevic, Z. (2009). Corporate Social Responsibility and Business Development: Case of Serbia. Monash University, Business and Economics,

Radivojević, V., Krstić, B., Krstić, M., \& Petković, M. (2019). Benchmarking agricultural and other environmental performances of Central and East European countries. Ekonomika poljoprivrede, 66(2), 471-484. doi:10.5937/ekoPolj1902471R

Rettab, B., Brik, A. B., \& Mellahi, K. (2009). A study of management perceptions of the impact of corporate social responsibility on organisational performance in emerging economies: the case of Dubai. Journal of Business Ethics, 89(3), 371-390. doi:10.1007/s10551-008-0005-9

Saeidi, S. P., Sofian, S., Saeidi, P., Saeidi, S. P., \& Saaeidi, S. A. (2015). How does corporate social responsibility contribute to firm financial performance? The mediating role of competitive advantage, reputation, and customer satisfaction. Journal of Business Research, 68(2), 341-350. doi:10.1016/j.jbusres.2014.06.024
Slavić, A., Berber, N., \& Aleksić, M. (2020) Relations Between Environmental Responsibility and EnviromentalPerformancies: an Evidence From Serbian. FerencFarkas $2^{\text {nd }}$ International Scientific Conference, Department of Leadership and Organizational Sciences at the Faculty of Business and Economics, University of Pecs, Hungary.In press

Turker, D. (2009). Measuring corporate social responsibility: A scale development study. Journal of business ethics, 85(4), 411-427. doi:10.1007\%252Fs10551-008-9780-6

Valdez-Juárez, L. E., Gallardo-Vázquez, D., \& RamosEscobar, E. A. (2018). CSR and the Supply Chain: Effects on the Results of SMEs. Sustainability, 10(7), 2356. doi:10.3390/su10072356

Vukadinović, S., \& Ješić, J. (2019). Green jobs: Potential for employment in the Republic of Serbia. Anali Ekonomskog fakulteta u Subotici, (41), 115129. doi:10.5937/AnEkSub1941115V

Vuković, A., Miletić, L. Z., Curčić, R., Ničić, M., \& Mitrović, N. (2020). Employees 'Perception of CSR in a Specific Post-Socialist Context: The Case of Serbia. JEEMS Journal of East European Management Studies, 25(1), 55-83. doi:10.5771/0949-6181-2020-1-55.

Weiss, A.M., Anderson, E., \&MacInnis, D. J. (1999). Reputation management as a motivation for sales structure decisions. Journal of Marketing, 63(4), 7489. doi: 10.1177/002224299906300407.

\title{
PRIMENA KORPORATIVNE DRUŠTVENE ODGOVORNOSTI I EKOLOŠKE PERFORMANSE PREDUZEĆA
}

\begin{abstract}
Godinama se, usled neodgovornog ponašanja pojedinaca i kompanija, stvaraju sve veći socijalni $i$ ekološki problemi širom sveta. Globalizacija, rast tržišta i industrijalizacija dovode do sve većih negativnih uticaja na prirodnu sredinu. Društveno odgovorno poslovanje je koncept u skladu sa kojim kompanija posvećuje pažnju ostvarenju rasta $i$ razvoja, ali i saradnji sa zaposlenima, lokalnim stanovništvom, potrošačima, poslovnim saradnicima i društvom u celini. U ovom radu će biti predstavljeni rezultati pilot istraživanja sprovedenog na teritoriji Republike Srbije. U istraživanju je učestvovalo 53 velike kompanije, u kojima ima preko 250 zaposlenih. Autori su u radu predstavili i vrednovali različite dimenzije društvenog odgovornog poslovanja i ekoloških performansi, te na osnovu dobijenih rezultata utvrdili da postoji statistički pozitivna veza između navedenih varijabli.
\end{abstract}

Ključne reči: Društveno odgovorno poslovanje; Životna sredina; Srbija. 